Article

\title{
New Nitrogen-Containing Recycled Fertilizers: Bioavailability of Nutrients and Harmful Elements
}

\author{
Janne Pesonen ${ }^{1, *(1)}$ and Pasi Rautio ${ }^{2}$ \\ 1 Research Unit of Sustainable Chemistry, University of Oulu, P.O. Box 4300, FI-90014 Oulu, Finland \\ 2 Natural Resource Institute Finland, Ounasjoentie 6, FI-96200 Rovaniemi, Finland; pasi.rautio@luke.fi \\ * Correspondence: janne.pesonen@oulu.fi; Tel.: +358-055726233
}

Received: 26 March 2019; Accepted: 10 April 2019; Published: 12 April 2019

\begin{abstract}
Environmental policies of the European Union aim to increase recycling and re-use of waste-streams. One of the economically most profitable ways of re-using waste is to use it as a fertilizer. In this study, recycled nitrogen fertilizers were manufactured from industrial side-streams (sawdust, fly-ash, ammonium sulfate and lignosulfonate). A sequential extraction procedure was applied to all the products tested in this paper to make sure that the environmental requirements of a recycled fertilizer would be fulfilled. A mass fraction of up to $7.0 \%$ of nitrogen was achieved with sawdust granule and $7.2 \%$ with fly-ash-sawdust granule, indicating that the granules would be well suited to be used as nitrogen-containing fertilizers. Nitrogen release from sawdust granule was more controlled than from commercial salpetre. Sawdust combined with fly-ash can hence give a balanced nutrient mix when used together. Bioavailabilities and pseudo-total contents of harmful elements ( $\mathrm{As}, \mathrm{Cd}, \mathrm{Cr}, \mathrm{Cu}, \mathrm{Ni}, \mathrm{Pb}$, and $\mathrm{Zn}$ ) were small in all granules and cause no harm in field or forest fertilizer use.
\end{abstract}

Keywords: ammonium; bioavailability; fly-ash; recycled fertilizers; sawdust; waste utilization

\section{Introduction}

The European Commission in its circular economy strategy is aiming to increase recycling and re-use of products and waste materials [1]. This strategy is linked to the Waste Framework Directive of the European Union [2] that includes 5-step waste hierarchy in which different options for dealing the waste are described. In this hierarchy, the first goal is to prevent waste-streams. If this is not possible, the next step down in the waste hierarchy is the preparation of waste for re-use, followed by recycling, other recovery (e.g., energy recovery) and, finally, if none of the initial four steps are feasible, waste should be disposed without harming the environment.

One of the economically most profitable ways of re-using waste is to use it as a fertilizer. This way one can replace artificial fertilizers, which have a relatively high carbon footprint due to their high-energy consumption in production phase, and still stay high on the 5-step waste hierarchy described above [3]. As an example, it has been estimated that in Finland alone the economic value of recycling nutrients is around 0.5 billion euros annually [4]. Besides the manure coming from animal husbandry, the most valuable sources of nutrients in wastes are combustion ashes and side-streams of facilities processing organic waste and sewage sludge $[5,6]$.

At the moment, a large part of the wood and peat ashes produced in the forest industry and power plants ends up at waste disposal sites, even though they could be re-used as fertilizers [5,7]. Wood fly-ash (FA), in particular, is rich in nutrients needed in plant nutrition. Of the major nutrients needed in plant growth and function, only nitrogen $(\mathrm{N})$ and sulphur $(\mathrm{S})$ are not present in FA, as they are released into the atmosphere during combustion [8]. In places that already have abundantly $\mathrm{N}$ in the soil, like large areas in Central-Europe, due to high $\mathrm{N}$-deposition or many peatlands, plain ash can 
work as a balanced fertilizer. For example, in peatlands, nitrogen levels are usually naturally high, whereas phosphorous $(\mathrm{P})$ and potassium $(\mathrm{K})$ are the growth limiting nutrients. It has in fact been shown that in peatland forests FA can outperform commercial PK fertilizers (phosphorous-potassium fertilizers) in increasing tree growth, as well as in financial performance [9-11]. In mineral soil forests and in most intensively cultivated agricultural fields, nitrogen is the growth limiting nutrient and should hence be applied with ash to make a balanced fertilizer.

To avoid problems caused by dust, FA needs to be granulated before spreading. Granulation is also a significantly more cost-effective alternative for ash recycling compared with unprocessed FA [12]. Co-granulation of FA with some nitrogen containing material, such as sewage sludge, could produce new fertilizer products to nitrogen poor soils [13]. Because sludges might also contain harmful elements, such as many synthetic organic substances [14], there has been attempts to extract $\mathrm{N}$ from sludges so that only the pure recycled nitrogen could be used as fertilizer. One method to separate $\mathrm{N}$ from sludge is to extract $\mathrm{N}$ from biogas plant digestate by stripping ammonia by sulfuric acid to form ammonium sulphate $\left(\left(\mathrm{NH}_{4}\right)_{2} \mathrm{SO}_{4}\right)$. However, ammonium evaporates easily as ammonia gas at alkaline conditions and therefore it is not easy to merge ammonium with alkaline matrix such as FA [15]. Here, we aim to test if we can modify FA so that amalgamation of ammonium sulphate is possible, or amalgamate ammonium sulphate with some other recycled media that can be granulated. This is the first study where such an attempt has been made.

Before waste can be reused as a fertilizer, it needs to fulfil quality levels as well as safety levels set by legislation. European environmental legislation requires that pseudo-total concentrations (i.e., acid-leachable metals that are not part of silicate matrix), and/or water-soluble concentrations of the harmful elements are studied from waste materials [7,16-19]. This, however, does not give reliable information of the environmental risks associated with the utilization or disposal of wastes. From the point of view of environment, it is not so important what the total concentration of e.g., heavy metals in wastes and other residues is, but rather how easily the metals can be mobilized from the inspected material into the environment. Water-soluble concentration is not a sufficient measure of the environmental risks because the distilled or deionized water used in the tests does not represent normal salt concentration or ionic strength of the soil solution [20]. Neither are these procedures sufficient to assess the bioavailability of nutrients from fertilizers. Therefore, to be able to better evaluate effects of different environmental conditions on bioavailability and mobility of different contaminants, sequential extraction methods have been widely used with different environmental samples during the last few decades [21-24]. In the sequential extraction procedure, different chemical reagents are applied to the sample in a series and each successive treatment is more drastic than the previous one. A sequential extraction procedure divides the total extractable metal concentration into fractions in order to assess the bioavailability and the form in which the metals occur in the studied material [25].

In this study, we aimed to find out if, by manipulating FA pH, we can add ammonium sulphate into FA to make a new type of nitrogen rich recycled fertilizer or if we can combine ammonium sulphate to some other recycled material to make a balanced fertilizer for all purposes. To make sure that our products would fulfill the environmental requirements of a recycled fertilizer, we applied a sequential extraction procedure to all the products tested here.

\section{Materials and Methods}

\subsection{Raw Materials and Granulation}

The FA used in this study was from a 96-MW (Megawatt) thermal power plant situated in Rovaniemi, Northern Finland. The power plant uses a circulating fluidized bed combustion technique. The fuels used at the plant are wood and peat. The fuel ratios (dry mass) at the power plant were approximately 50\% wood (logging residue) and 50\% peat. The sample was collected 14 May 2014 directly from ash silo. Commercial $350 \mathrm{~g} \mathrm{~L}^{-1}$ ammonium sulfate solution stripped from a biogasification process (Envor, Finland), $850 \mathrm{~g} \mathrm{~L}^{-1}$ phosphoric acid (Sigma-Aldrich, St. louis, MO, United States) and 
lignosulfonate from a pulp and paper mill (Borregaard, Norway) was used in the granulation process. Sawdust (SD) came from a sawmill situated in Northern Finland.

The compositions of the granules manufactured in this study are presented in Table 1. Granule FA was a control sample that contained only FA and water. Previous study [15] indicated that if ammonium sulphate is mixed with FA, the ammonium evaporates as ammonia gas due to the high $\mathrm{pH}$ of FA, and therefore ammonium cannot be added directly to the FA granules. In this study, phosphoric acid was used to: (i) control the $\mathrm{pH}$ of FA; (ii) to bring extra phosphorus to the granules; and (iii) to act as a binding agent. Phosphorus acid dissolves silicon and aluminum from FA to form a geopolymer framework [26], which keeps the granule in one piece. SD was used either alone or with FA as a matrix to absorb ammonium. Lignosulfonate was used as a binding agent for SD-based granules.

Table 1. Composition and sample names of the granules. FA = fly ash; $\mathrm{SD}=$ sawdust; $\mathrm{PA}=$ phosphoric acid.

\begin{tabular}{cc}
\hline Sample & Composition (Mass Fraction (\%)) \\
\hline FA & $60 \%$ fly ash; $40 \%$ water \\
\hline FAPA & $61.3 \%$ fly ash; $12.3 \%$ phosphoric acid; $26.4 \%$ ammonium sulphate solution \\
\hline FASD & $19.2 \%$ fly ash; $19.2 \%$ sawdust; $9.6 \%$ lignosulfonate; $3.8 \%$ phosphoric acid; \\
& $48.1 \%$ ammonium sulphate solution \\
\hline SD & $28.6 \%$ sawdust; $14.3 \%$ lignosulfonate; $57.1 \%$ ammonium sulphate solution \\
\hline
\end{tabular}

All granules were manufactured the same way: all dry matter was carefully agitated using a ribbon blade agitator until a homogenous mixture was achieved. Solution was then slowly added, while still agitating the mixture, until small aggregates started to form in the paste. Granules were formed simply by rolling the paste in the hand until firm, spherical granules were achieved (diameter approx. $20 \mathrm{~mm})$. The granules were cured at room temperature $\left(21 \pm 2{ }^{\circ} \mathrm{C}\right)$ for at least 28 days. $\mathrm{pH}$-values of all manufactured granules was between 5-6 (liquid to solid ratio L S${ }^{-1}=10 \mathrm{~L} \mathrm{~kg}^{-1}$ ); therefore, there were no ammonia losses.

\subsection{Analysis Methods}

Granules were crushed and sieved to a particle size smaller than $0.5 \mathrm{~mm}$ before analyses. Nitrogen contents were analyzed using a Perkin Elmer 2400 series II CHNS-analyzer at the University of Oulu (Waltham, MA, United States).

The pseudo-total element concentrations were characterized by aqua regia digestion according to standard ISO 11466 [27] and analyzed with the inductively coupled plasma optical emission spectrometry (ICP-OES) technique at an accredited laboratory. The 4-step sequential extraction procedure (Table 2) used in this study is based on the Community Bureau of Reference (BCR) procedure [28]. Stages 2 to 4 follow the BCR procedure, but the first stage involves extraction with deionized water acidified to $\mathrm{pH} 4$ with $\mathrm{HNO}_{3}$ [29]. The purpose of the first stage is to simulate the effect of acidic rainwater-present day rain —on the solubility of the metals. This 4-step sequential leaching procedure has been used successfully with samples including bottom ash and FA [29-32]. The eluates from each step were separated from the residue by centrifuging for $20 \min (\mathrm{RCF}=3000)$ and analyzed using the ICP-OES technique at an accredited laboratory. Duplicate samples from each batch were analyzed, and the averages were calculated. However, the F4 result for FA granule is based on a single measurement due to errors made in the leaching stage.

The moisture contents of the FA and the FA granules were measured according to standard SFS-EN 12880 [33] by drying the samples in a hot air oven for $24 \mathrm{~h}$ at $105 \pm 2{ }^{\circ} \mathrm{C}$. The dried samples were placed in cooling desiccators and weighed. However, the samples were not dried prior the sequential leaching procedure, since heat can affect the leaching of elements [34]. Instead, the moisture contents were taken into account as the leaching results were calculated. The moisture mass fractions of the samples were: $1.6 \%$ for FA; $5.2 \%$ for FAPA; $5.7 \%$ for FASD; and $4.2 \%$ for SD. 
Table 2. 4-step sequential leaching procedure [28,29]. Mass of the sample was 1 gram at the first stage.

\begin{tabular}{|c|c|c|c|}
\hline Step & Fraction & Extractant & Experimental Conditions \\
\hline F1 & Water-soluble & $40 \mathrm{~cm}^{3} \mathrm{H}_{2} \mathrm{O}$ at pH 4 (with $\mathrm{HNO}_{3}$ ) & $16 \mathrm{~h}$ at $22 \pm 5^{\circ} \mathrm{C}$, constant shaking \\
\hline $\mathrm{F} 2$ & $\begin{array}{l}\text { Exchangeable and } \\
\text { acid soluble }\end{array}$ & $40 \mathrm{~cm}^{3}$ HOAc $0.11 \mathrm{~mol} \mathrm{~L}^{-1}$ & $16 \mathrm{~h}$ at $22 \pm 5^{\circ} \mathrm{C}$, constant shaking \\
\hline F3 & Reducible & $\begin{array}{c}40 \mathrm{~cm}^{3} \mathrm{NH}_{2} \mathrm{OH} \cdot \mathrm{HCl} 0.5 \mathrm{~mol} \mathrm{~L}^{-1} \\
\text { at pH } 1.5\left(\text { with } \mathrm{HNO}_{3}\right)\end{array}$ & 16 h at $22 \pm 5^{\circ} \mathrm{C}$, constant shaking \\
\hline \multirow{3}{*}{$\mathrm{F} 4$} & \multirow{3}{*}{ Oxidizable } & $10 \mathrm{~cm}^{3} \mathrm{H}_{2} \mathrm{O}_{2} 300 \mathrm{~g} \mathrm{~L}^{-1}$ & $\begin{array}{l}1 \mathrm{~h} \text { at } 22 \pm 5^{\circ} \mathrm{C} \text {, occasional manual } \\
\text { shaking, then } 1 \mathrm{~h} 85 \pm 2{ }^{\circ} \mathrm{C} \text {. Reduce } \\
\text { the volume to less than } 3 \mathrm{~cm}^{3}\end{array}$ \\
\hline & & $10 \mathrm{~cm}^{3} \mathrm{H}_{2} \mathrm{O}_{2} 300 \mathrm{~g} \mathrm{~L}^{-1}$ & $1 \mathrm{~h}$ at $85 \pm 2{ }^{\circ} \mathrm{C}$ \\
\hline & & $\begin{array}{c}50 \mathrm{~cm}^{3} \mathrm{NH}_{4} \mathrm{OAc} 1 \mathrm{~mol} \mathrm{~L}^{-1} \\
\left.\text { at pH } 2 \text { (with } \mathrm{HNO}_{3}\right)\end{array}$ & $16 \mathrm{~h}$ at $22 \pm 5^{\circ} \mathrm{C}$ \\
\hline
\end{tabular}

The fractions of the 4-step sequential extraction are the water-soluble fraction; exchangeable and acid-soluble fraction; reducible fraction; and oxidizable fraction [21]. In theory, the first fraction should contain water-soluble ions. This fraction is the most mobile, and it contains potentially the most readily available metal and metalloid species. The second fraction should contain metals bonded electrostatically, metals bonded with weak covalent bonds, or metals bonded to carbonates. The third fraction should contain metals bonded to $\mathrm{Mn}$ and Fe oxides, and the fourth fraction metals bonded to organic matter or to different sulfides and oxides. In the present study, the first two fractions (F1 and F2) are referred to as easily bioavailable fractions. The total bioavailability refers to the sum of the fractions (F1-F4) [21,28,35].

\subsection{Leaching Trial}

Leaching rate of ammonium sulphate absorbed to the SD was studied in an ad hoc laboratory experiment. In the experiment, nine plastic funnels (diameter $20 \mathrm{~cm}$ ) were positioned in a sturdy support to keep the funnels in place. Each funnel was filled with inert quartz sand in nylon back so that a few centimeters of the top of the funnel remained free (Figure A1 in Appendix A). Each of the funnels was randomized to receive one of the following three treatments: (i) sample SD (i.e., ammonium sulphate absorbed to SD and lignosulphonate), (ii) commercial nitrogen fertilizer (salpetre, i.e., ammonium nitrate) and (iii) control (plain quartz sand). Each of the three treatments was replicated three times. Both treatments (i) and (ii) had the same amount of nitrogen (the level corresponds to $120 \mathrm{~kg}$ of $\mathrm{N}$ per hectare in practical forest fertilization). Each funnel was watered with 1.58 litres of milliQ water ( $\mathrm{pH}$ 5.6, i.e., equal to clean rain water) five times. Between each watering, there was at least one day, so that the fertilizers had time to dry between the waterings. The water leaching through the funnels was collected in glass sample bottles positioned below the funnels (Figure A1 in Appendix A). Each watering was collected separately so that from each funnel there was in total five water samples. Water samples were then filtered and analysed for total nitrogen (ammonium + nitrate + nitrite $\mathrm{mg} \mathrm{L}^{-1}$ ). The data were statistically analysed by linear mixed model analysis. In the model (completely randomized design), the treatment (fertilizers) and the watering time were fixed factors and the funnel was a random factor. The five water samples collected from each funnel are not independent samples but repeated measures from the same subject hence first-order autoregressive (AR1) covariance structure was used for the watering time factor. The data was log-transformed before the analysis. The data analysis was performed using IBM SPSS Statistics ver. 25 (Armonk, NY, United States). 


\section{Results and Discussion}

\subsection{Contents and Leaching of Nutrients}

The pseudo-total contents of nutrients Calcium (Ca), potassium (K), magnesium (Mg), phosphorus $(\mathrm{P})$, sulphur $(\mathrm{S})$, and nitrogen $(\mathrm{N})$ are presented in Table 3. The SD granule contained only very small amounts of $\mathrm{Ca}, \mathrm{K}, \mathrm{P}$ or $\mathrm{Mg}$, but the ammonium sulfate addition was clearly visible as high $\mathrm{N}$ and $\mathrm{S}$ concentrations. A mass fraction of $7.0 \%$ and $7.2 \%$ of $\mathrm{N}$ was achieved with the SD and FASD granules. The phosphoric acid functioned also well, since a mass fraction of $2.5 \%$ of $\mathrm{N}$ was measured in the FAPA granule and the P content was increased 573\% compared to the FA granule. The downside is that, as more phosphorus is added, the potassium concentration is decreased (due to the dilution). Since the content of $\mathrm{K}$ and $\mathrm{P}$ was quite low in the original FA, the granule does not completely fulfill the Finnish limit values for $\mathrm{K}+\mathrm{P}$. The Ca content exceeded the minimum requirements of Finnish Fertilizer Product Decree 24/2011 [30] for forest fertilizers. Finnish legislation does not recognize SD-based fertilizers, but the closest classification is organic mineral fertilizers (a mixture of organic and mineral nutrients). They must contain a mass fraction of at least $7 \% \mathrm{~N}+\mathrm{P}+\mathrm{K}$, which is fulfilled here. C:N ratios of the granules were 0.06 for FAPA; 4.29 for SD; and 3.37 for FASD.

Table 3. Pseudo-total contents of nutrients $\mathrm{Ca}, \mathrm{K}, \mathrm{Mg}, \mathrm{P}, \mathrm{S}$, and total contents of $\mathrm{N}$ in the fertilizer granules and the limit values of Finnish Fertilizer Product Decree 24/2011 for ash fertilizers used in silviculture [19].

\begin{tabular}{|c|c|c|c|c|c|c|}
\hline Granule & $\mathrm{Ca}\left(\mathrm{g} \mathrm{kg}^{-1}\right)$ & $K\left(\mathrm{~g} \mathrm{~kg}^{-1}\right)$ & $P\left(\mathrm{~g} \mathrm{~kg}^{-1}\right)$ & $\operatorname{Mg}\left(\mathrm{g} \mathrm{kg}^{-1}\right)$ & $\mathrm{S}\left(\mathrm{g} \mathrm{kg}^{-1}\right)$ & $\mathbf{N}$ (mass fraction $(\%)$ ) \\
\hline FA & 83.9 & 8.05 & 9.97 & 14.7 & 7.89 & 0.0 \\
\hline FAPA & 76.7 & 5.67 & 67.1 & 13.8 & 38.8 & 2.5 \\
\hline FASD & 37.6 & 2.72 & 24.6 & 5.45 & 75.8 & 7.2 \\
\hline SD & 0.82 & 0.58 & 0.07 & 0.70 & 113 & 7.0 \\
\hline Limit value & $\geq 60$ & $K+P \geq 20$ & & & & \\
\hline
\end{tabular}

The total bioavailability $\left(\sum \mathrm{F}_{\mathrm{i}}\right)$ and the amounts of easily bioavailable $(\mathrm{F} 1+\mathrm{F} 2)$ the nutrients $\mathrm{Ca}, \mathrm{K}$, $\mathrm{Mg}, \mathrm{P}$, and $\mathrm{S}$ are presented in Table 4. Sulphur was almost completely in easily bioavailable form in all granules. The amount of easily soluble phosphorus was also high in granules FAPA $\left(28.9 \mathrm{~g} \cdot \mathrm{kg}^{-1}\right)$ and FASD $\left(11.1 \mathrm{~g} \cdot \mathrm{kg}^{-1}\right)$ due to the PA addition. PA increased also the amount of easily bioavailable $\mathrm{Ca}, \mathrm{K}$ and $\mathrm{Mg}$ even though their pseudo-total concentration was smaller than in FA. Therefore, the quick-acting fertilizer effect increases considerably after PA addition.

The leaching test shows that, from both the commercial fertilizer (salpetre) and the SD sample ((NH4)2SO4 in SD), nitrogen leached rapidly, but, in SD, nitrogen remained a bit longer before reaching the zero concentration (Figure 1). This is seen also in the statistical analysis that shows that not only treatment (fertilizer) and watering but also their interaction is statistically significant (sig. $<0.05$, Table A1 in Appendix B). This result suggests that nitrogen absorbed to SD is more slowly released than $\mathrm{N}$ in commercial salpetre. This was also observed when doing the watering: salpetre granules dissolved more or less completely already during the first watering. The amount of water used in the trial $(5 \times 1.58$ litres $=7.9$ litres $)$ equals to the amount of summertime precipitation in Rovaniemi where the leaching trial was carried out. Thus, the fact that commercial fertilizer dissolved this easily suggests that, in forests, it can actually totally dissolve already during the first rain, whereas $\mathrm{N}$ in SD is leached more evenly during the growing season. 
Table 4. Amounts of easily bioavailable fractions and total bioavailability of nutrients $\mathrm{Ca}, \mathrm{K}, \mathrm{Mg}, \mathrm{P}$, and S; standard deviations are in parentheses.

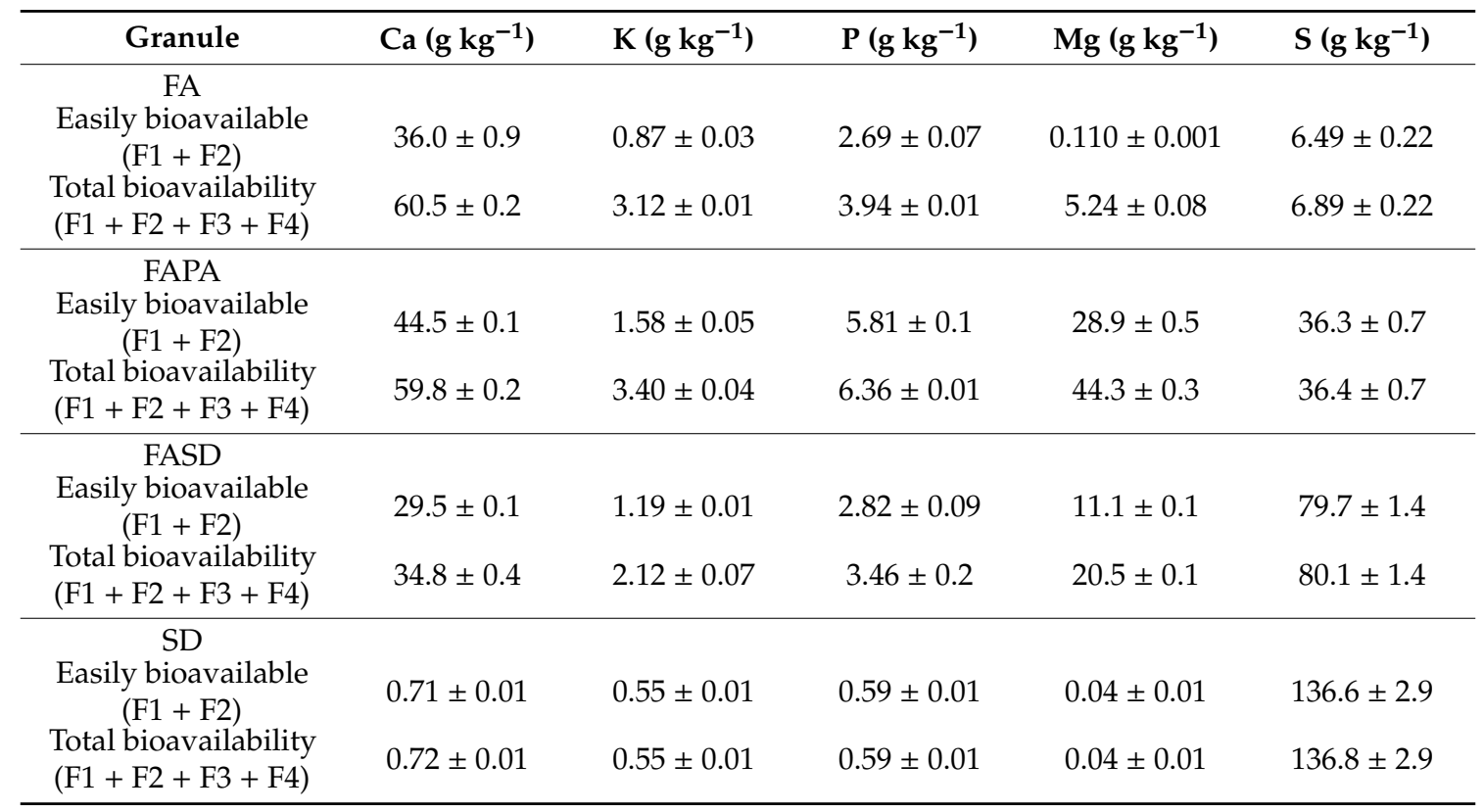

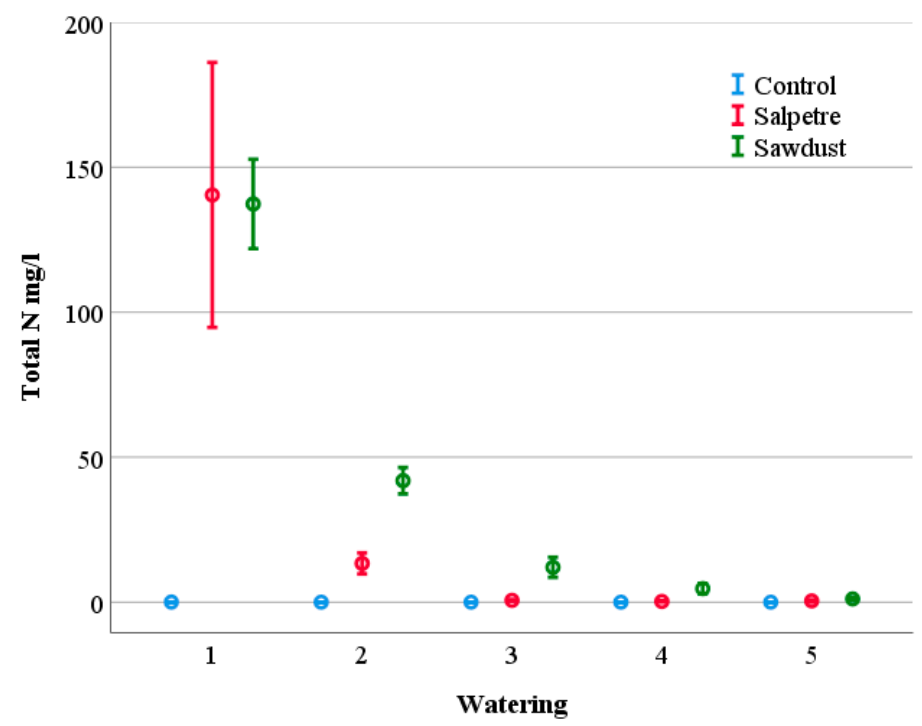

Figure 1. Concentration of total nitrogen $\left(\mathrm{NH}_{4}-\mathrm{N}+\mathrm{NO}_{2}-\mathrm{N}+\mathrm{NO}_{3}-\mathrm{N}, \mathrm{mg} \mathrm{L}^{-1}\right)$ in water collected on five occasions below funnels on top of which salpetre or ammonium sulphate absorbed to sawdust were positioned. Funnels with no fertilizers functioned as control treatment. The values are mean $( \pm 1 \mathrm{SE})$ of three replicates $(\mathrm{SE}=$ Standard error).

\subsection{Contents and Leaching of Harmful Elements}

The pseudo-total contents of nutrients harmful elements arsenic (As), cadmium (Cd), chrome $(\mathrm{Cr})$, copper $(\mathrm{Cu})$, nickel $(\mathrm{Ni})$, lead $(\mathrm{Pb})$, and zinc $(\mathrm{Zn})$ are presented in Table 5. All harmful element concentrations were well below the limit values of Finnish fertilizer decree for both forest and field fertilizers and, especially in the SD granule, the concentrations were very low. One concern was that the phosphoric acid would increase the solubility of harmful elements, but instead the solubilities were smaller. This is most likely due to the formation of the geopolymer structure and the dilution effect caused by phosphoric acid addition. However, industrial-grade phosphoric acid is typically used in the fertilizer industry, which can contain more impurities than the analytical-grade acid used 
here. Therefore, the leaching of harmful elements can be somewhat larger than in this study, still, the phosphoric acid itself does not increase the leaching of elements.

Table 5. Pseudo-total contents of harmful elements $\mathrm{As}, \mathrm{Cd}, \mathrm{Cr}, \mathrm{Cu}, \mathrm{Ni}, \mathrm{Pb}$, and $\mathrm{Zn}$ and the limit values of Finnish Fertilizer Product Decree 24/2011 [19].

\begin{tabular}{|c|c|c|c|c|c|c|c|}
\hline & $\begin{array}{c}\text { As } \\
\left(\mathrm{mg} \mathrm{kg}^{-1}\right)\end{array}$ & $\begin{array}{c}\mathrm{Cd} \\
\left(\mathrm{mg} \mathrm{kg}^{-1}\right)\end{array}$ & $\begin{array}{c}\mathrm{Cr} \\
\left(\mathrm{mg} \mathrm{kg}^{-1}\right)\end{array}$ & $\begin{array}{c}\mathrm{Cu} \\
\left(\mathrm{mg} \mathrm{kg}^{-1}\right)\end{array}$ & $\begin{array}{c}\mathrm{Ni} \\
\left(\mathrm{mg} \mathrm{kg}^{-1}\right)\end{array}$ & $\begin{array}{c}\mathrm{Pb} \\
\left(\mathrm{mg} \mathrm{kg}^{-1}\right)\end{array}$ & $\begin{array}{c}\mathrm{Zn} \\
\left(\mathrm{mg} \mathrm{kg}^{-1}\right)\end{array}$ \\
\hline FA & 18 & 1.4 & 66 & 76 & 47 & 33 & 270 \\
\hline FAPA & 17 & 1.8 & 52.2 & 64.6 & 44.2 & 22.3 & 217 \\
\hline FASD & 7.2 & 0.67 & 21.2 & 34.9 & 16.5 & 8.7 & 95.4 \\
\hline SD & $<1.05$ & $<0.07$ & 1.2 & 0.71 & 46 & $<1.03$ & 8.42 \\
\hline Limit value & & & & & & & \\
\hline $\begin{array}{l}\text { Field/forest } \\
\text { fertilizers }\end{array}$ & $25 / 40$ & $2.5 / 25$ & $300 / 300$ & $600 / 700$ & $100 / 150$ & $100 / 150$ & $1500 / 4500$ \\
\hline
\end{tabular}

Sequential extraction results of the harmful elements $\mathrm{As}, \mathrm{Cd}, \mathrm{Cr}, \mathrm{Cu}, \mathrm{Ni}, \mathrm{Pb}$, and $\mathrm{Zn}$ are presented in Table 6. Due to problems in the sequential leaching procedure, the F4 fraction of FA granule is based on a single measurement. For SD granule, the sequential extraction results were mainly below the detection limits. However, Ni seemed to be in a highly soluble form. The source of Ni in SD granules was most likely the lignosulfonate powder since a different batch of lignosulfonate was used for the SD and FASD granules. In both FAPA and FASD, the amount of easily soluble harmful elements was very small compared to the pseudo-total contents. In addition, the total bioavailabilities of $\mathrm{Cr}, \mathrm{Cu}, \mathrm{Ni}$, $\mathrm{Pb}$ and $\mathrm{Zn}$ were small. Therefore, the leaching of harmful elements would not cause environmental risks in fertilizers use.

Table 6. Sequential extraction results of harmful elements $\mathrm{As}, \mathrm{Cd}, \mathrm{Cr}, \mathrm{Cu}, \mathrm{Ni}, \mathrm{Pb}$, and $\mathrm{Zn}$. Standard deviations are in parentheses.

\begin{tabular}{|c|c|c|c|c|c|c|c|}
\hline & $\begin{array}{c}\text { As } \\
\left(\mathrm{mg} \mathrm{kg}^{-1}\right)\end{array}$ & $\begin{array}{c}\mathrm{Cd} \\
\left(\mathrm{mg} \mathrm{kg}^{-1}\right)\end{array}$ & $\begin{array}{c}\mathrm{Cr} \\
\left(\mathrm{mg} \mathrm{kg}^{-1}\right)\end{array}$ & $\begin{array}{c}\mathrm{Cu} \\
\left(\mathrm{mg} \mathrm{kg}^{-1}\right)\end{array}$ & $\begin{array}{c}\mathrm{Ni} \\
\left(\mathrm{mg} \mathrm{kg}^{-1}\right)\end{array}$ & $\begin{array}{c}\mathrm{Pb} \\
\left(\mathrm{mg} \mathrm{kg}^{-1}\right)\end{array}$ & $\begin{array}{c}\mathrm{Zn} \\
\left(\mathrm{mg} \mathrm{kg}^{-1}\right)\end{array}$ \\
\hline FA & & & & & & & \\
\hline $\mathrm{F} 1$ & $<1.2$ & $<0.04$ & $0.4 \pm 0.1$ & $<0.1$ & $<0.1$ & $<0.4$ & $<0.1$ \\
\hline F2 & $<1.2$ & $0.41 \pm 0.01$ & $0.9 \pm 0.1$ & $2.9 \pm 0.1$ & $2.7 \pm 0.1$ & $0.9 \pm 0.1$ & $19 \pm 1$ \\
\hline F3 & $5.2 \pm 0.1$ & $0.33 \pm 0.01$ & $1.8 \pm 0.1$ & $7.3 \pm 0.5$ & $0.9 \pm 0.1$ & $9.0 \pm 1$ & $18 \pm 1$ \\
\hline $\mathrm{F} 4$ & $<1.5$ & $<0.05$ & 1.0 & 2.5 & 0.3 & 3.5 & 3.1 \\
\hline \multicolumn{8}{|l|}{ FAPA } \\
\hline F1 & $2.0 \pm 0.1$ & $0.04 \pm 0.01$ & $0.08 \pm 0.01$ & $7.1 \pm 0.4$ & $1.9 \pm 0.1$ & $<0.40$ & $0.10 \pm 0.01$ \\
\hline F2 & $1.2 \pm 0.1$ & $0.21 \pm 0.01$ & $0.08 \pm 0.01$ & $1.3 \pm 0.1$ & $1.3 \pm 0.1$ & $<0.40$ & $29 \pm 0.9$ \\
\hline F3 & $3.4 \pm 0.1$ & $0.15 \pm 0.01$ & $7.5 \pm 0.1$ & $5.3 \pm 0.1$ & $0.85 \pm 0.01$ & $5.5 \pm 0.1$ & $17 \pm 1$ \\
\hline $\mathrm{F} 4$ & $2.0 \pm 0.1$ & $0.06 \pm 0.01$ & $5.2 \pm 0.9$ & $5.8 \pm 0.8$ & $1.6 \pm 0.5$ & $3.3 \pm 0.2$ & $9.0 \pm 2.6$ \\
\hline \multicolumn{8}{|l|}{ FASD } \\
\hline F1 & $3.1 \pm 0.1$ & $0.04 \pm 0.01$ & $0.08 \pm 0.01$ & $0.08 \pm 0.01$ & $1.3 \pm 0.1$ & $<0.39$ & $<0.1$ \\
\hline F2 & $1.2 \pm 0.1$ & $0.27 \pm 0.01$ & $0.08 \pm 0.01$ & $1.2 \pm 0.1$ & $3.2 \pm 0.1$ & $<0.39$ & $11 \pm 1$ \\
\hline F3 & $7.5 \pm 0.1$ & $0.74 \pm 0.01$ & $5.4 \pm 0.1$ & $12 \pm 1$ & $0.98 \pm 0.01$ & $2.6 \pm 0.01$ & $57 \pm 1$ \\
\hline $\mathrm{F} 4$ & $1.5 \pm 0.1$ & $0.05 \pm 0.01$ & $1.8 \pm 0.1$ & $0.77 \pm 0.06$ & $0.36 \pm 0.06$ & $1.8 \pm 0.1$ & $1.7 \pm 0.1$ \\
\hline \multicolumn{8}{|l|}{ SD } \\
\hline F1 & $<1.2$ & $<0.04$ & $0.83 \pm 0.03$ & $0.37 \pm 0.08$ & $40 \pm 1$ & $<0.39$ & $7.9 \pm 0.1$ \\
\hline F2 & $<1.2$ & $<0.04$ & $<0.08$ & $0.08 \pm 0.01$ & $2.4 \pm 0.3$ & $<0.39$ & $0.56 \pm 0.07$ \\
\hline F3 & $<1.2$ & $<0.04$ & $<0.08$ & $0.13 \pm 0.02$ & $0.71 \pm 0.15$ & $<0.39$ & $0.16 \pm 0.06$ \\
\hline $\mathrm{F} 4$ & $<1.5$ & $<0.05$ & $<0.10$ & $0.17 \pm 0.01$ & $<0.15$ & $<0.49$ & $0.16 \pm 0.06$ \\
\hline
\end{tabular}

\section{Conclusions}

Recycled nitrogen fertilizers were manufactured from industrial side-streams (sawdust (SD), fly-ash (FA), ammonium sulfate and lignosulfonate). Phosphoric acid (PA) was used to control the $\mathrm{pH}$ and to add extra phosphorus to the granules. Bioavailability of nutrients and heavy metals from recycled fertilizers was studied using leaching tests. A mass fraction of up to $7.0 \%$ of $\mathrm{N}$ was achieved 
with the SD granule and 7.2\% with the FA-SD granule, indicating that the granules would be well suited to be used as nitrogen-containing fertilizers. Nitrogen release from SD granule was more controlled than from commercial salpetre, indicating that $\mathrm{N}$ is released from the SD granule more evenly during the growing season than from commercial salpetre. $\mathrm{P}$ and $\mathrm{K}$ concentrations of FAPA granule $(72.8 \mathrm{~g}$ $\left.\mathrm{kg}^{-1} \mathrm{~K}+\mathrm{P}\right)$ and FASD granule $\left(27.3 \mathrm{~g} \mathrm{~kg}^{-1} \mathrm{~K}+\mathrm{P}\right)$ clearly exceeded the Finnish limit values for forest fertilizers (limit value $\mathrm{K}+\mathrm{P} \geq 20 \mathrm{~g} \mathrm{~kg}^{-1}$ ). Sulphur was almost completely in easily bioavailable form in all granules. The amount of easily soluble phosphorus was also high in granules FAPA $\left(28.9 \mathrm{~g} \cdot \mathrm{kg}^{-1}\right)$ and FASD (11.1 $\left.\mathrm{g} \mathrm{kg}^{-1}\right)$ due to the PA addition. SD combined with FA can hence give a balanced nutrient mix when used together. Bioavailabilities and pseudo-total contents of harmful elements (As, $\mathrm{Cd}, \mathrm{Cr}, \mathrm{Cu}, \mathrm{Ni}, \mathrm{Pb}$, and $\mathrm{Zn}$ ) were small in all granules and caused no harm in field or forest fertilizer use. PA decreased the bioavailabilities of harmful elements due to the formation of the geopolymer structure and the dilution effect caused by PA addition.

Author Contributions: Conceptualization, J.P. and P.R.; methodology, J.P. and P.R.; investigation, J.P. and P.R.; writing—original draft preparation, J.P.; writing—review and editing, P.R.; funding acquisition, P.R.

Funding: This work was done under the auspices of the Biotuhka (Bioash) ERDF Project (project no: A70101, funded by North Ostrobothnia Centre for Economic Development, Transport and the Environment; Napapiirin Vesi ja Energia Ltd.; Napapiirin Residuum Ltd. and Rovaniemen Kehitys Ltd.).

Acknowledgments: The staff at the Natural Resources Institute Finland laboratory in Rovaniemi and in Vantaa are acknowledged for the laboratory analyses.

Conflicts of Interest: The authors declare no conflict of interest. The funders had no role in the design of the study; in the collection, analyses, or interpretation of data; in the writing of the manuscript, or in the decision to publish the results.

\section{Appendix A}

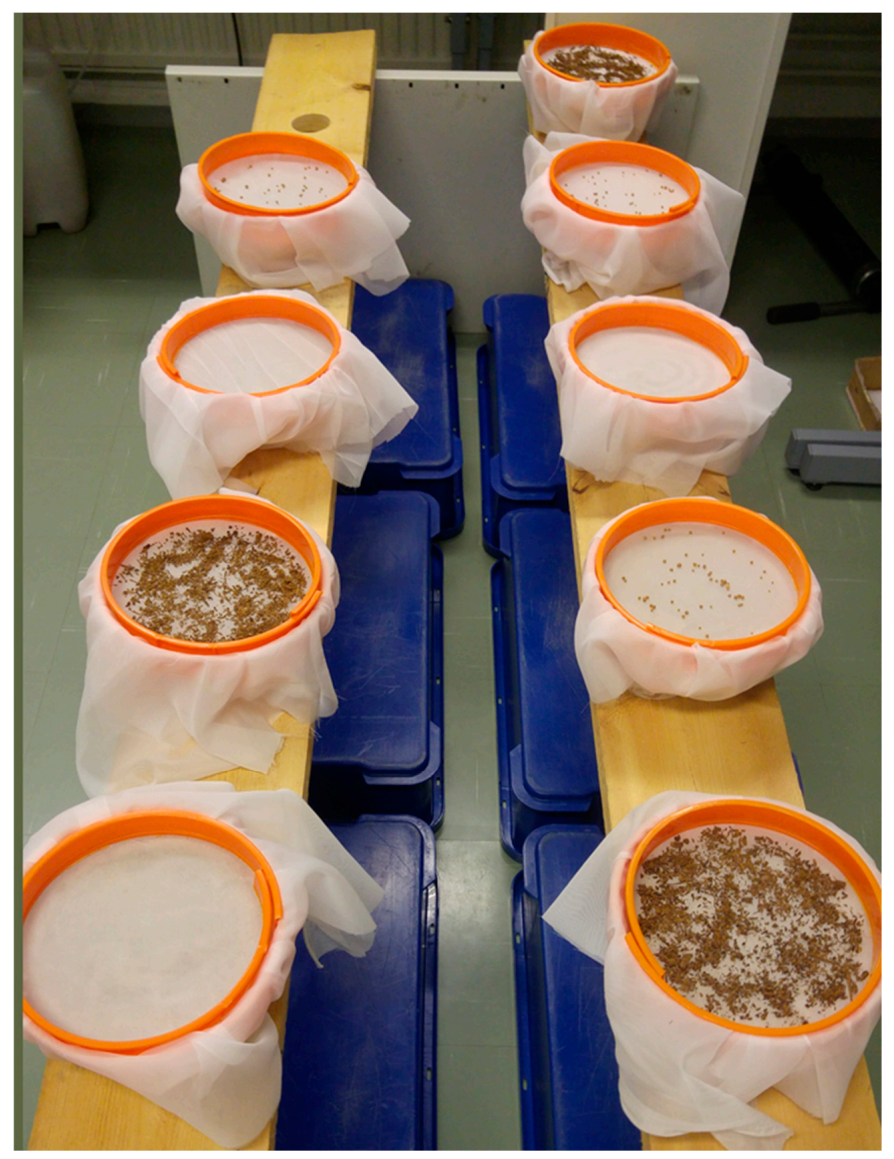

Figure A1. Cont. 


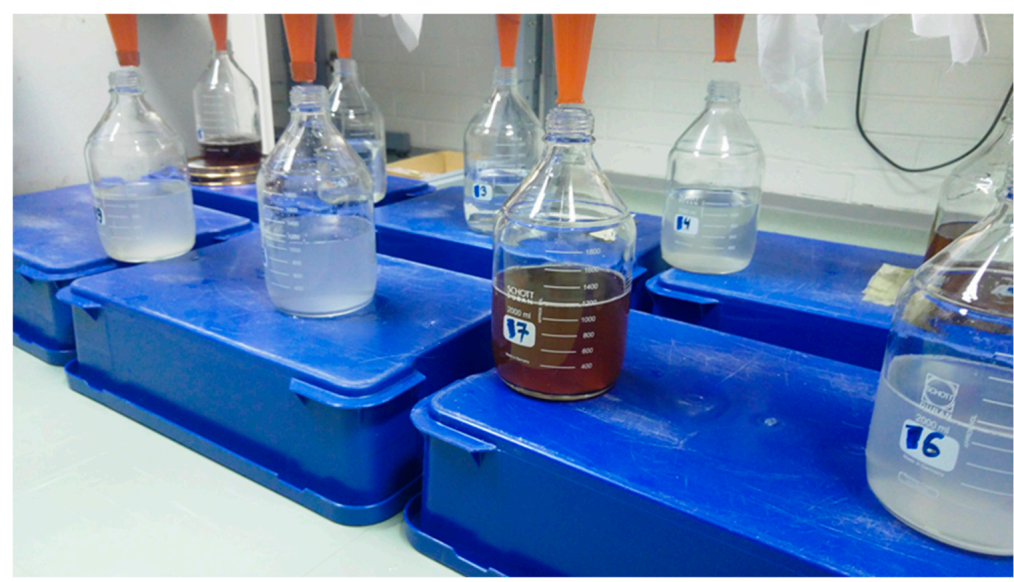

Figure A1. Experimental set-up in the leaching experiment showing the nine funnels (top picture) that were filled with inert quartz sand on which the fertilizers were positioned or left empty (control). Water leaching through the funnels was collected to glass bottles placed below the funnels before each watering (bottom picture).

\section{Appendix B}

Table A1. Results of analysis of variance for the total nitrogen concentrations (log-transformed mg 1-1) in the water samples collected in the laboratory experiment. For treatment (fertilizer), watering time and their interaction $\mathrm{df}$ (numerator/denumerator), F-value and the significance is given.

\begin{tabular}{cccc}
\hline Source & df & F & Sig. \\
\hline Intercept & $1 / 4.6$ & 19.88 & 0.008 \\
Treatment & $2 / 4.6$ & 104.31 & 0.000 \\
Watering & $4 / 17.9$ & 22.62 & 0.000 \\
Treatment $\times$ Watering & $8 / 17.9$ & 3.98 & 0.007 \\
\hline
\end{tabular}

\section{References}

1. European Commission Circular Economy Strategy. Available online: http://ec.europa.eu/environment/ circular-economy/index_en.htm (accessed on 19 February 2018).

2. European Commission. Directive 2008/98/EC of the European Parliament and of the Council of 19 November 2008 on Waste and Repealing Certain Directives; European Commission: Brussels, Belgium, 2008.

3. Wood, S.; Cowie, A. A Review of Greenhouse Gas Emission Factors for Fertiliser Production; IEA Bioenergy Task 38: Sydney, Australia, 2004.

4. Aho, M.; Pursula, T.; Saario, M.; Miller, T.; Kumpulainen, A.; Päällysaho, M.; Autio, M.; Hillgren, A.; Descombes, L. Ravinteiden Kierron Taloudellinen Arvo ja Mahdollisuudet SUOMELLE (Econimic Value and Possibilites of Nutrient Recycling for Finland); Sitran selvityksiä; Sitra: Helsinki, Finland, 2015; p. 50.

5. Ojala, E. Selvitys puu- ja Turvetuhkan Lannoite- Sekä Muusta Hyötykäytöstä (Report on the Utilization of Wood and Peat Based Ash as A Fertilizer and in Other Applications); Motiva: Helsinki, Finland, 2010.

6. Sanna, M.; Venelampi, O.; Iho, A.; Koikkalainen, K.; Lehtonen, E.; Luostarinen, S.; Rasia, K.; Sarvi, M.; Tampio, E.; Turtola, E.; et al. Kohti Ravinteiden Kierrätyksen Läpimurtoa (Towards the Breakthrough of Nutrent Recycling); Luonnonvara- ja biotalouden tutkimus: Helsinki, Finland, 2017.

7. Hannam, K.D.; Deschamps, C.; Kwiaton, M.; Venier, L.A.; Hazlett, P.W. Regulations and Guidelines for the Use of Wood Ash as A Soil Amendment in Canadian Forests; Information Report GLC-X-17; Natural Resources Canada, Canadian Forest Service, Great Lakes Forestry Centre: Ottawa, ON, Canada, 2016.

8. Karltun, E.; Saarsalmi, A.; Ingerslev, M.; Mandre, M.; Andersson, S.; Gaitnieks, T.; Ozolinčius, R.; Varnagiryte-Kabasinskiene, I. Wood Ash Recycling-Possibilities and Risks. In Sustainable Use of Forest Biomass for Energy: A Synthesis with Focus on the Baltic and Nordic Region; Röser, D., Asikainen, A., Eds.; Springer Netherlands: Dordrecht, The Nederland, 2008; pp. 79-108. ISBN 978-1-4020-5054-1. 
9. Moilanen, M.; Hytönen, J.; Hökkä, H.; Ahtikoski, A. Fertilization increased growth of Scots pine and financial performance of forest management in a drained peatland in Finland. Silva Fenn. 2015, 49, 1-18. [CrossRef]

10. Moilanen, M.; Silfverberg, K.; Hökkä, H.; Issakainen, J. Comparing effects of wood ash and commercial PK fertiliser on the nutrient status and stand growth of Scots pine on drained mires. Balt. For. 2004, 10, 2-10.

11. Pugliese, S.; Jones, T.; Preston, M.D.; Hazlett, P.; Tran, H.; Basiliko, N. Wood ash as a forest soil amendment: The role of boiler and soil type on soil property response. Can. J. Soil Sci. 2014, 94, 621-634. [CrossRef]

12. Rasmusson, H.; Sarenbo, S.; Claesson, T. Ash Products and Their Economic Profitability. Open Waste Manag. J. 2013, 6, 1-5. [CrossRef]

13. Pesonen, J.; Kuokkanen, V.; Kuokkanen, T.; Illikainen, M. Co-granulation of bio-ash with sewage sludge and lime for fertilizer use. J. Environ. Chem. Eng. 2016, 4, 4817-4821. [CrossRef]

14. Lindberg, R.; Sahlén, K.; Tysklind, M. Occurrence and Distribution of Synthetic Organic Substances in Boreal Coniferous Forest Soils Fertilized with Hygienized Municipal Sewage Sludge. Antibiot. Basel Switz. 2013, 2, 352-366. [CrossRef] [PubMed]

15. Pesonen, J.; Kuokkanen, T.; Rautio, P.; Lassi, U. Bioavailability of nutrients and harmful elements in ash fertilizers: Effect of granulation. Biomass Bioenergy 2017, 100, 92-97. [CrossRef]

16. European Commission. Council Directive 1999/31/EC of 26 April 1999 on the Landfill of Waste; European Commission: Brussels, Belgium, 1999.

17. European Commission. Council Directive 86/278/EEC of 12 June 1986 on the Protection of the Environment, and in Particular of the Soil, When Sewage Sludge is Used in Agriculture; European Commission: Brussels, Belgium, 1986.

18. Ministry of the Environment. Valtioneuvoston Asetus Eräiden Jätteiden Hyödyntämisestä Maarakentamisessa (Government Decree on the Recovery of Certain Waste in Earth Construction) 843/2017. Available online: https://www.finlex.fi/fi/laki/alkup/2017/20170843 (accessed on 20 February 2018).

19. Ministry of Agriculture and Forestry. Maa-ja Metsätalousministeriön Asetus Lannoitevalmisteista 24/11 (Ministry of Agriculture and Forestry Decree on Fertilizer Products 24/11); Ministry of Agriculture and Forestry: Helsinki, Finland, 2011.

20. Kaakinen, J.; Kuokkanen, T.; Kujala, K.; Välimäki, I.; Jokinen, H. The Use of a Five-stage Sequential Leaching Procedure for Risk Assessment of Heavy Metals in Waste Rock Utilized in Railway Ballast. Soil Sediment Contam. Int. J. 2012, 21, 322-334. [CrossRef]

21. Filgueiras, A.V.; Lavilla, I.; Bendicho, C. Chemical sequential extraction for metal partitioning in environmental solid samples. J. Environ. Monit. 2002, 4, 823-857. [CrossRef] [PubMed]

22. Zhang, J.; Li, H.; Zhou, Y.; Dou, L.; Cai, L.; Mo, L.; You, J. Bioavailability and soil-to-crop transfer of heavy metals in farmland soils: A case study in the Pearl River Delta, South China. Environ. Pollut. 2018, 235, 710-719. [CrossRef]

23. Thanh, P.M.; Ketheesan, B.; Yan, Z.; Stuckey, D. Trace metal speciation and bioavailability in anaerobic digestion: A review. Biotechnol. Adv. 2016, 34, 122-136. [CrossRef]

24. Reis, L.S.; de Andrade Gonçalves, É.C.B. Chemical speciation: An instrument for evaluation of mineral bioavailability. Cienc. Rural 2015, 45, 1126-1132. [CrossRef]

25. Lorentzen, E.M.L.; Kingston, H.M. "Skip" Comparison of Microwave-Assisted and Conventional Leaching Using EPA Method 3050B. Anal. Chem. 1996, 68, 4316-4320. [CrossRef]

26. Douiri, H.; Louati, S.; Baklouti, S.; Arous, M.; Fakhfakh, Z. Structural, thermal and dielectric properties of phosphoric acid-based geopolymers with different amounts of H3PO4. Mater. Lett. 2014, 116, 9-12. [CrossRef]

27. International Organization of Standardization. ISO 11466:1995-Soil Quality-Extraction of Trace Elements Soluble in Aqua Regia; International Organization of Standardization: Geneva, Switzerland, 1995.

28. Rauret, G.; López-Sánchez, J.F.; Sahuquillo, A.; Rubio, R.; Davidson, C.; Ure, A.; Quevauviller, P. Improvement of the BCR three step sequential extraction procedure prior to the certification of new sediment and soil reference materials. J. Environ. Monit. JEM 1999, 1, 57-61. [CrossRef]

29. Nurmesniemi, H.; Pöykiö, R.; Kuokkanen, T.; Perämäki, P.; Välimäki, I. Sequential leaching of trace elements in bottom ash from a fluidized bed co-combustion boiler at a pulp and paper mill complex. J. Solid Waste Technol. Manag. 2005, 31, 115-121. 
30. Kuokkanen, T.; Pöykiö, R.; Nurmesniemi, H.; Rämö, J. Sequential leaching of heavy metals and sulfur in bottom ash and fly ash from the co-combustion of wood and peat at a municipal district heating plant. Chem. Speciat. Bioavailab. 2006, 18, 131-142. [CrossRef]

31. Nurmesniemi, H.; Pöykiö, R.; Kuokkanen, T.; Rämö, J. Chemical sequential extraction of heavy metals and sulphur in bottom ash and in fly ash from a pulp and paper mill complex. Waste Manag. Res. 2008, 26, 389-399. [CrossRef]

32. Pöykiö, R.; Nurmesniemi, H.; Perämäki, P.; Kuokkanen, T.; Välimäki, I. Leachability of metals in fly ash from a pulp and paper mill complex and environmental risk characterisation for eco-efficient utilization of the fly ash as a fertilizer. Chem. Speciat. Bioavailab. 2005, 17, 1-10. [CrossRef]

33. Finnish Standards Association. SFS-EN 12880 Characterization of Sludges. Determination of Dry Residue and Water Content; Finnish Standards Association: Helsinki, Finland, 2001.

34. Kosson, D.S.; Van, D.S.; Sanchez, F.; Garrabrants, A.C. An Integrated Framework for Evaluating Leaching in Waste Management and Utilization of Secondary Materials. Environ. Eng. Sci. 2002, 19, 159-204. [CrossRef]

35. Tessier, A.; Campbell, P.G.C.; Bisson, M. Sequential extraction procedure for the speciation of particulate trace metals. Anal. Chem. 1979, 51, 844-851. [CrossRef]

(C) 2019 by the authors. Licensee MDPI, Basel, Switzerland. This article is an open access article distributed under the terms and conditions of the Creative Commons Attribution (CC BY) license (http://creativecommons.org/licenses/by/4.0/). 